Article

\title{
ANALYSIS OF WRF SIMULATION SKILL FOR SEASONAL RAINFALL: A CASE STUDY OF 2015 SEPTEMBER-NOVEMBER SEASON
}

\author{
Ronald Odongo Ingula ${ }^{1}$, Isaac Mugume ${ }^{1,2, *}$ \\ 1 Department of Geography, Geo-informatics \& Climatic Sciences, Makerere University, P. O. Box 7062, \\ Kampala, Uganda; odongoronieplanks@gmail.com \\ 2 Hub for Environmental \& Atmospheric Research, Kampala, Uganda; amooti23@gmail.com \\ * Correspondence: imugume@caes.mak.ac.ug; Tel.: +256-779-721822
}

\begin{abstract}
Rainfall is a major climate parameter whose variation in space and time influences activities in different weather sensitive sectors such as agriculture, transport, and energy among others. Therefore, accurately forecasting rainfall is of paramount importance to the development of these sectors. In this regard, this study sought to contribute to quantitative forecasting of rainfall over Eastern Uganda through assessing the Weather Research and Forecasting model's ability to simulate the intra-seasonal characteristics of the September to December rain season. These were: onset and cessation dates; wet days and lengths of the wet spells. The data used in the study included daily ground rainfall observations and lateral and boundary conditions data from the National Centers for Environmental Prediction (NCEP) final analysis at $1^{0}$ horizontal resolution and at a temporal resolution of 6 hours for the entire study period were used to initialize the Weather Research and Forecasting (WRF) model. The study considered four weather synoptic weather stations namely; Jinja, Serere, Soroti and Tororo. The results show that the WRF model generally simulated fewer wet days at each station except for Tororo. Also, the WRF model simulated earlier onset and cessation dates of the rainfall season and overestimated the length of the wet spells.
\end{abstract}

Keywords: Intra-Seasonal rain fall characteristics; Short rains; WRF Model

\section{Introduction}

Precipitation refers to all liquid and frozen forms of water falling from the sky to the earth's surface by action of gravitational force and it manifests in various forms (such as rainfall, snow, hail, drizzle and sleet [1-3]. Over East Africa and Uganda in particular precipitation is mainly in the form of rainfall $[3,4]$. The rainfall pattern over Uganda shows a large spatio-temporal variability which is attributed to the complex topography [5-7]; and existence of large inland water bodies (Lakes such as; Victoria, Kyoga, Albert and rivers (e.g. the Nile and the Aswa) which modulate the local climate system $[5,6]$.

The economy of East African countries largely depends on rain-fed agriculture [4-6]. In Uganda for example, the agricultural sector contributes $26 \%$ of the country's Gross Domestic Product $[5,8]$. As such, variations in the distribution of rainfall amounts both in space and time significantly impacts the agricultural sector and consequently the economy [3,9]. The rainfall variability is often associated with devastating socio-economic impacts resulting in loss of life and property [8]; food insecurity [9]; water shortages [3]; power and communication interruptions [10] among others. In Uganda, for example, over a thousand people of Kanamba and Kabaka parishes in Karusandara sub-county (Kasese district) were left homeless after River Mubuku flooded and busted its banks, washing away crops and destroying property worth millions of money[4]. Omondi et al[4] observed that there is an increase in 
the frequency of droughts over in the horn of Africa in recent years. This has been linked to the global climate change [11-13], which has been associated with the spatial and temporal decline in rainfall [14-17] and also increased the number of cases of food insecurity and resource based conflicts [18-20]. In this regard, timely information on the spatio-temporal rainfall patterns is essential for effectively managing the rainfall dependent socio-economic sectors and for disaster risk reduction.

Among the climate sensitive sectors which are affected by precipitation, the agricultural sector is most prone to the variability in the precipitation amounts received globally $[13,17,21]$. In most parts of Africa and particularly East Africa, agriculture being predominantly rain-fed, it makes it very vulnerable to the changes in precipitation [21-23]. Thus, the uneven seasonal distribution of precipitation may expose crops to severe intra-seasonal dry and wet spells $[17,21]$. This in return affects the yields at the end of the season [24-27]. A study by Wang et al.[28] showed that the changes in the intra-seasonal rainfall characteristics especially onset and cessation have caused crop failure. This is further exacerbated by land degradation $[17,27]$. Therefore understanding the intra-seasonal rainfall characteristics (e.g. onset, wet-spells, dry-spells and cessation) is key in decision making and resource management especially for crop production.

However, limited efforts have been made over Uganda to model the intra-seasonal rainfall characteristics. Many of the previous studies e.g. Bouagila and Sushama[27] focused on the inter-annual rainfall variability at monthly, seasonal and annual timescales; Ngailo et al.[29] modeled extreme rainfall over Dar es Salaam. With the demand for improved quantitative rainfall prediction [3], it is crucial that numerical experiments are designed that target intra-seasonal rainfall characteristics. This is because, as the earth's climate continues to change over time, the characteristics of the regional precipitation, intra-seasonal seasonal characteristics and the extreme events may change without necessary being reflected in seasonal totals $[8,12,14]$. This study investigates the skill of the Weather Research and Forecasting (WRF Version 3.9) model [30] to simulate the intra-seasonal rainfall characteristics. The rest of the paper is presented as Section (2) presenting materials used in the study including the study methods and data sources; Section (3) presenting the results while Section (4) summarizes the findings.

\section{Materials and Methods}

\subsection{Study Area}

studyArea

The study was considered eastern Uganda (Figure1) because it is one of the parts of the country with many cases of hydrological related/induced disasters including landslides that frequently occur in Budduda as reported by Kansiime \& Shisanya[31] and the occurrence of these landslides is attributed to the prolonged wet spells over the region. As of 2019, the eastern region of Uganda comprise 32 districts and is located between the latitude span of $0.5^{\circ} \mathrm{N}-2^{\circ} \mathrm{N}$ and longitude of $33.5^{\circ} \mathrm{E}-35.0^{\circ} \mathrm{E}$. However, this study used 4 locations, namely: Soroti, Serere, Jinja and Tororo due to the availability of climatic data for groundtruthing. 


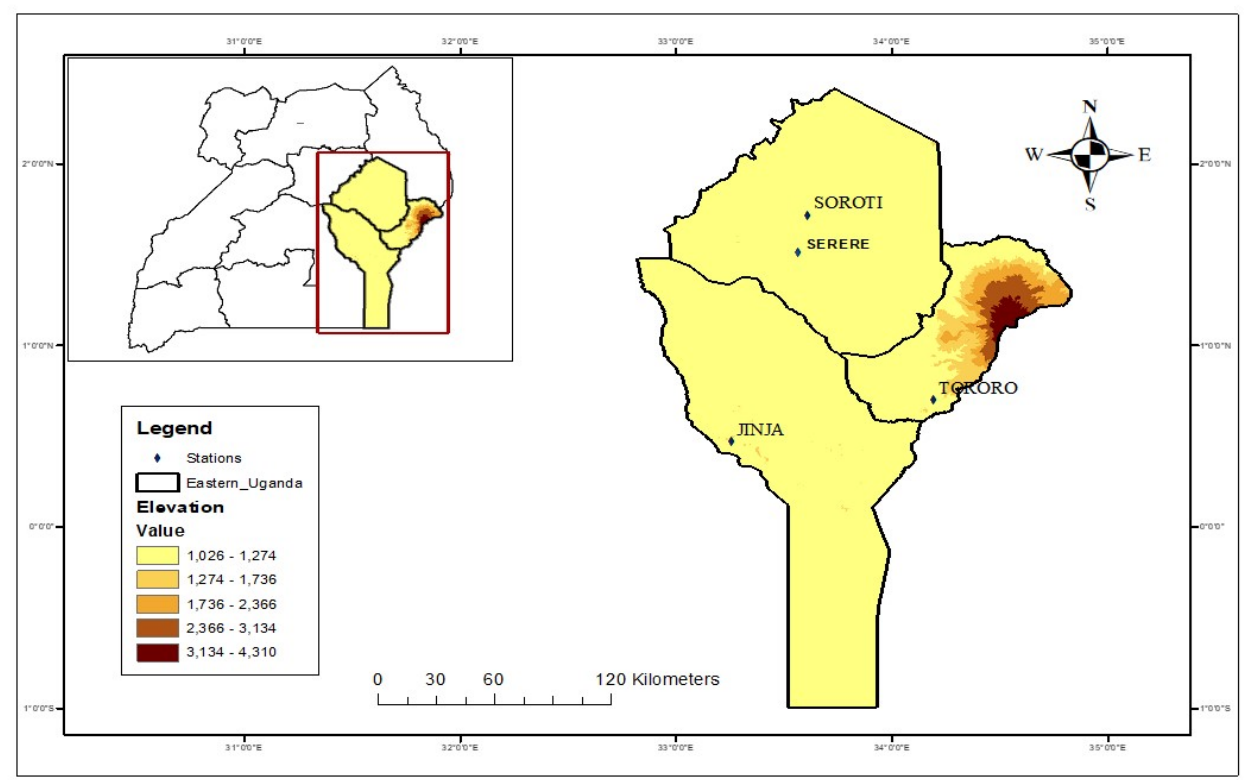

Figure 1. A map showing the study region. Inset is the map of Uganda showing the major regions of the country including the eastern region which is the study area.

\subsection{The climatology of the study area}

Eastern Uganda experiences bi-modal rainfall seasons that is the March to May and September to November seasons each year [31-33]. The rainfall received in the region just like the other parts of the country, is greatly influenced by the inter-tropical convergence zone [21,33]; the monsoon wind circulations [32]; and the local influences that is to say the land and sea breezes due to the presence of lake Victoria, orographic lifting due to the presence of Mt. Elgon [21]. The geographical details of the study sites are presented using Table 1

Table 1. Showing geographical data of study area.

\begin{tabular}{lrrr}
\hline Station & Latitude (degrees) & Longitude (degrees) & Altitude(meters) \\
\hline Jinja & 0.451 & 33.196 & 1126.4 \\
\hline Tororo & 0.679 & 34.168 & 1428.8 \\
\hline Soroti & 1.722 & 33.619 & 1142.6 \\
\hline Serere & 1.501 & 33.547 & 1141.5 \\
\hline
\end{tabular}

\subsection{Data and Its Sources}

The dataset used in the study included the lateral and boundary conditions data (at $1^{\circ} \times 1^{o}$ horizontal resolution and at 6 hourly interval) from the National Centers for Environmental Prediction (NCEP) final analysis and the daily observed rainfall observations obtained from the Uganda National Meteorological Authority. The daily gauged rainfall data comprised of the observations made from four weather stations presented using Table 1 . The data are for the period from $1^{\text {st }}$ September to $31^{\text {st }}$ December of 2015.

\subsection{Experimental Design}

The study was conducted using the WRF model version 3.9 [30] with 32 vertical levels projected using the Mercator map projection. The domains used are presented using Figure 2. The parent domain was at $110 \mathrm{Km}$ horizontal resolution centered at $0.73^{\circ} \mathrm{N}$ and $21.0^{E}$. The parent domain had $85 \times 85$ grid points sufficient to cover the whole of Africa and capturing the large-scale systems influencing 
rainfall over the study region such as the sub-tropical high-pressure systems and the inter-tropical convergence zone $[21,32]$.

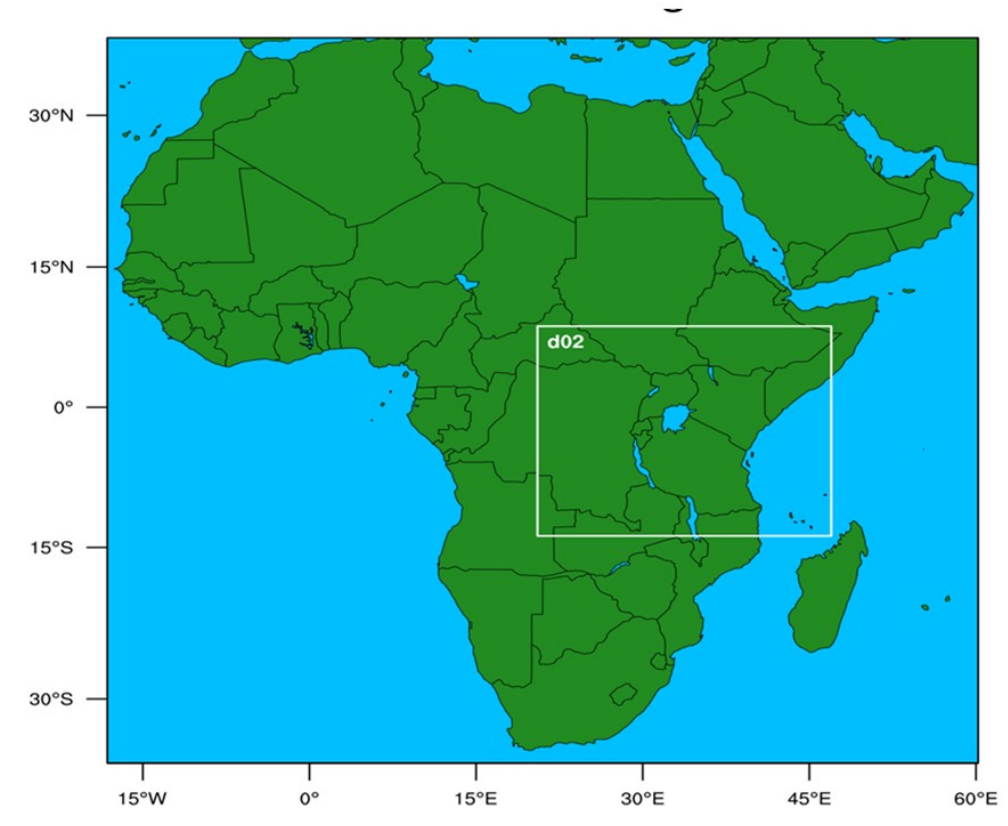

Figure 2. Domain configuration used for the WRF model experiment.

The nested domain was at $22 \mathrm{Km}$ horizontal resolution spanning $136 \times 116$ grid points covering most parts of the equatorial regions of Africa so as to capture the systems that affect the moisture influx over Uganda [25] such as Congo air mass from the Congo basin in West and the moist currents from the Mozambique channel in the Indian Ocean [32]. The two domains were set at a grid ratio of $1: 5$ with a two-way nested interaction and the integration was carried out using the Runge-Kutta $2^{\text {nd }}$ order option. The study also used the Kain-Fritsch cumulus parameterization scheme [22,34]; the WRF Single-Moment 6-Class Microphysics Scheme [35].

\subsection{Methodology}

The study first computed the rainfall onset/cesseation for the observed data using a statistical software known as INSTAT [36]. The study then simulated daily rainfall using WRF model for the two domains (i.e. d01 the parent domain and d02 the nest domain) for a similar September-December rainfall period, namely from $1^{\text {st }}$ September to $31^{\text {st }}$ December 2015 . The simulated daily rainfall values were then used to compute the onset/cessation using INSTAT.

To determine the onset, an accumulated rainfall total of at least $20 \mathrm{~mm}$ in two days at a threshold $1 \mathrm{~mm}$ was adopted $[11,36,37]$. There should be no dry spell of duration 9 days or more in the next 30 days $[11,26,37]$. The study considered $1^{\text {st }}$ September as the earliest date. This study considered the end of the September-November rainy season as any day after the $1^{\text {st }}$ of December, when the soil water balance reaches zero[16,23]. This study also considered a fixed average $5 \mathrm{~mm}$ of evapotranspiration per day and $100 \mathrm{~mm} /$ meter of the maximum soil water holding capacity of the area as suggested by Gebremichael et al.[23].

The performance of WRF model was evaluated using the mean error (ME) and the root mean square error (RMSE). The ME is a parametric measure used in many numerical simulations for assessing the possibility of bias of a numerical model [37-39]. It is presented mathematical using Equation 1.

$$
M E=\frac{1}{n} \sum_{i=1}^{n}\left(f_{i}-O_{i}\right)
$$


where; $f_{i}$ is the simulated value; $O_{i}$ is the observed value and $n$ is the number of data points used. The study also used the RMSE for assessing the average error magnitude of WRF. This is suggested by Kumi \& Abiodun[37] and presented according to Mugume[22] using Equation 2.

$$
R M S E=\sqrt{\frac{\sum_{i=1}^{n}\left(f_{i}-O_{i}\right)^{2}}{n}}
$$

In evaluating the skill of WRF to simulate the wet days and wet spells, a wet day was defined as a day having accumulated precipitation of more than $1 \mathrm{~mm}[22,33]$. The wet spell is defined as a period of $k$ continuous rainy days having rainfall greater than $1 \mathrm{~mm}[15,20,33]$. This was done using the INSTAT software [36].

Comparisons between the simulated wet days and the observed was done through a Pearson correlation analysis [31] to assess if there existed any linear relationship between the derived wet spells from the model outputs and the derived wet spells from observation data in order to assess the models' skill in simulating wet days. The equation for determining the Pearson correlation coefficient, $r_{x y}$ is given in Equation 3

$$
r_{x y}=\frac{\sum_{t=1}^{N-|K|}\left(X_{t}-X\right)\left(Y_{t+k}-Y\right)}{\sqrt{\left(\sum_{t=1}^{N}\left(X_{t}-X\right)\right)}\left(\sum_{t=1}^{N}\left(Y_{t}-Y\right)\right)}
$$

where $r_{x y}$ is the Pearson correlation coefficient between dependent variable $\mathrm{X}$ and independent variable $Y$ at a time lag k. $X_{t}$ and $Y_{t}$ are dependent and independent variables at time $t . N$ is the length of the variable records. The simultaneous simple correlation coefficient is obtained by setting $k$ to zero in Equation 3. The significance of the value of the calculated correlation $r_{x y}$ was tested using $t$-test (equation 4) on assumption of confidence level at $95 \%$ and significance level of $P(0.05)$.

$$
t=\sqrt{\frac{n-2}{1-r^{2}}}
$$

\section{Results and discussion}

\subsection{Simulation of the rainfall onset dates by the WRF model}

The results presented below (Table 2) are onset dates as observed at different stations and how the model simulates the different onset dates at different stations. The negative values (Table 2 ) indicate the number of days the WRF model simulated an earlier onset date of the rainfall season thank observed while the positive values indicate the number of days the model simulated an later onset date for a given station.

Table 2. Shows the observed and simulated (domain 1and domain 2) Onset dates over study region for the 2015 SOND rainfall season. The "Lag" is the difference between simulated and observed.

\begin{tabular}{|l|l|l|l|r|r|}
\hline Station & Observed Onset & \multicolumn{2}{|c|}{ Simulated Onset } & \multicolumn{2}{c|}{ Lag( $\triangle$ in days) } \\
\hline & & Domain 1 & Domain 2 & Domain 1 & Domain 2 \\
\hline Jinja & 2nd September & 4th September & 2nd September & 2 & 0 \\
Tororo & 11th September & 4th September & 2nd September & -7 & -9 \\
Soroti & 1st September & 2nd September & 2nd September & 1 & 1 \\
Serere & 4th September & 2nd September & 2nd September & -2 & -2 \\
\hline & & & Mean & -1.5 & -2.5 \\
\hline
\end{tabular}

The results (Table 2) show that the WRF model generaly simulated earlier onset dates of the rainfall season for Tororo and Serere stations at all the model resolutions unlike for Soroti where the model simulated a later onset date by a day and for Jinja, the model captured the onset date $\left(2^{\text {nd }}\right)$ for the start of the rainfall season for domain 2 and for domain 1 the model was lagged by two days. Generally, for all the onset dates the model for domain two did not agree with the observations at 
any station however, it had better results at Soroti station where the difference was only one day and the worst for Tororo station with a difference of 7 days. A similar study by Dunning et al.[40] using gridded rainfall data found East Africa in general having 3-11 days variation in onset. Our results are thus in agreement with the findings of Dunning et al.[40].

\subsection{Simulation of the Cessation dates}

Table 3 shows that observed and simulated (domain 1 \& domain 2) 2015 September-December seasonal rainfall cessation dates. The negative values indicates that the rainfall cessation as simulated by the WRF model was earlier than observed.

Table 3. Shows the observed and simulated rainfall cessation dates. The Lag ( $\triangle$ in days) is the difference between the cessation dates from the observed and the simulated datasets.

\begin{tabular}{|l|c|c|c|c|c|}
\hline Station & Observed Cessation & \multicolumn{2}{|c|}{ Simulated Cessation } & \multicolumn{2}{c|}{ Lag( $\triangle$ in days) } \\
\hline & & Domain 1 & Domain 2 & Domain 1 & Domain 2 \\
\hline Jinja & $31^{\text {st }}$ December & $12^{\text {th }}$ November & $9^{\text {th }}$ December & -49 & -22 \\
Tororo & $25^{\text {th }}$ December & $10^{\text {th }}$ November & $14^{\text {th }}$ December & -45 & -11 \\
Soroti & $31^{\text {st }}$ December & $12^{\text {th }}$ November & $10^{\text {th }}$ December & -49 & -21 \\
Serere & $31^{\text {st }}$ December & $10^{\text {th }}$ December & $17^{\text {th }}$ December & -21 & -14 \\
\hline & & & Mean & -41 & -17 \\
\hline
\end{tabular}

The results presented in Table 3 generally show that WRF model simulates an earlier cessation than observed. However, the results for the second domain seem to suggest a better performance compared to the results presented by the first domain. The $t$-test results show a significantly better performance with a $p_{-}$value of 0.03 . The failure by the WRF model to replicate the onset and cessation dates is probably due to incomplete description of atmospheric behavior [22] and inappropriate combination of physical parameterization schemes [22,41] among others.

\subsection{Simulation of wet days in the SOND season of 2015.}

The results for the total number of wet simulated by the WRF model at different stations are presented in Table 4.

Table 4. Cessation dates both the observed and the simulated by WRF for the SOND season of 2015 with the difference ( $\triangle$ in days) between the cessation dates from the observed and the simulated datasets.

\begin{tabular}{lrrr}
\hline Station & Observed & Domain 1 & Domain 2 \\
\hline Jinja & 52 & 65 & 66 \\
Tororo & 63 & 77 & 56 \\
Soroti & 37 & 46 & 54 \\
Serere & 71 & 53 & 54 \\
\hline
\end{tabular}

Analysis of the results shows that WRF model over estimated the total number of wet days at Tororo and Soroti stations for both the resolutions and it underestimated the number of wet days at Serere station. Generally the WRF model overestimated the total number of wet observed for that study period.

Additional analysis was done by plotting time series graphs to compare WRF model's performance at different stations and at the different resolutions. Results (Figure 3) shows that for all the stations the model failed to simulate heavy rainfall greater than $40 \mathrm{~mm}$. Error analysis shows that Tororo had a lower root mean square, RMSE (9.24) index. 

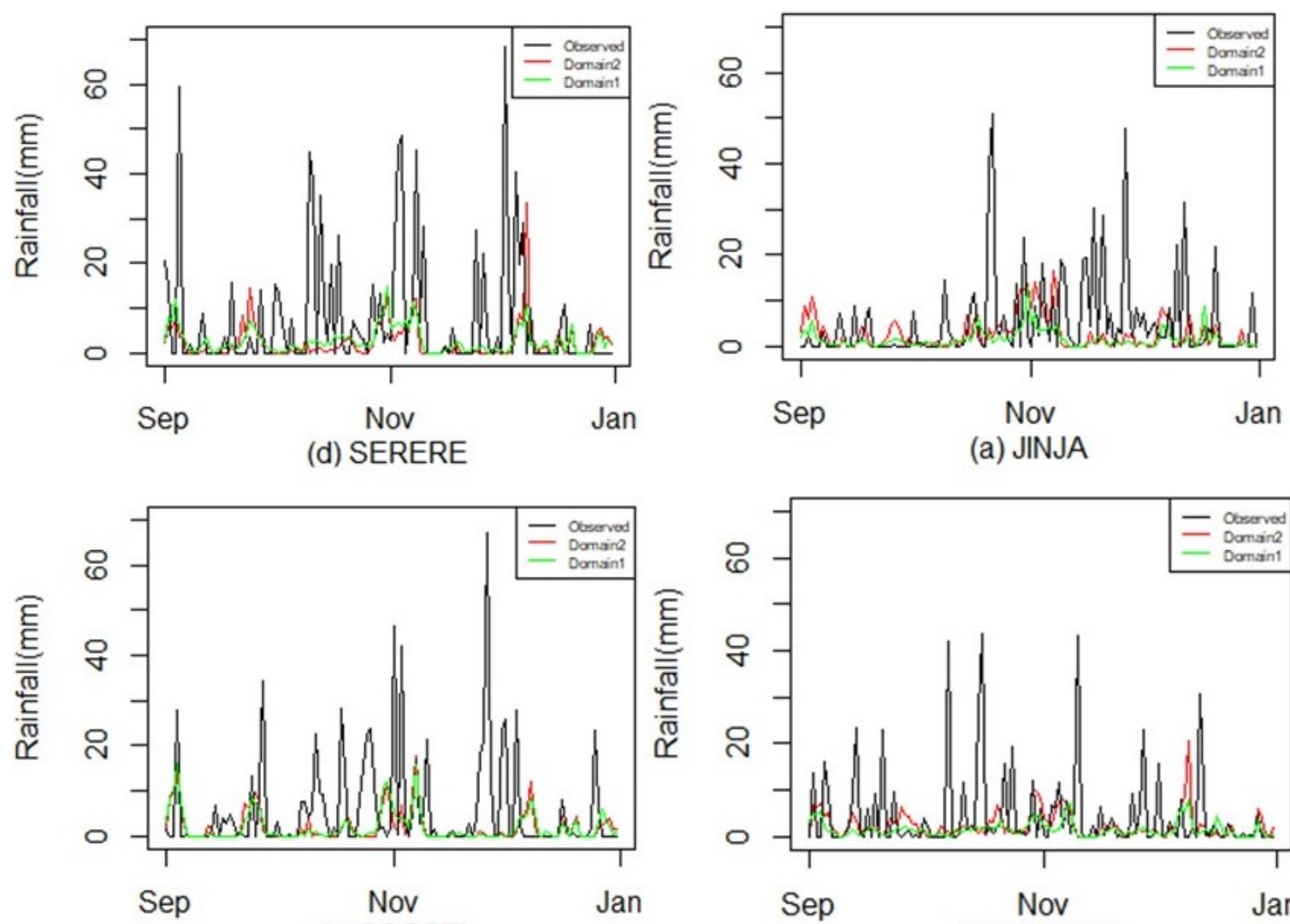

(c) SOROTI

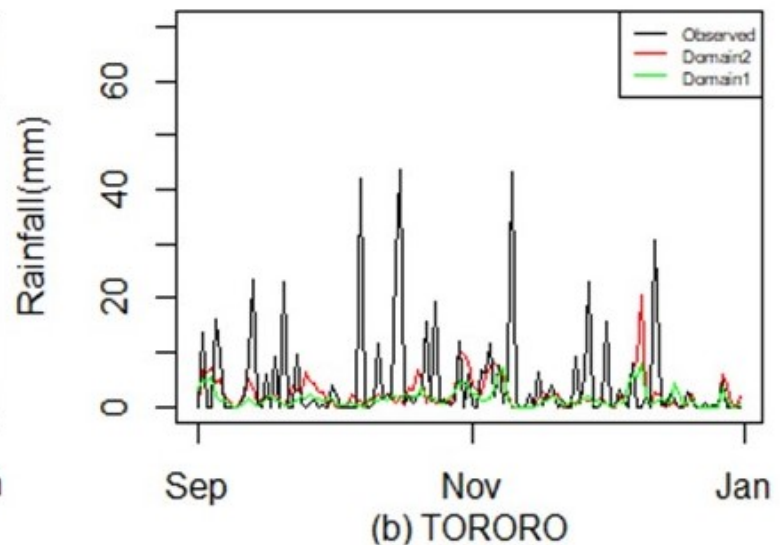

Figure 3. Time series showing the representation of rainfall simulated by WRF at different stations; Serere (a), Jinja (b), Soroti (c) and Tororo (d).

\subsection{Simulation of the lengths of wet-spells}

Table 5 shows duration of the longest wet-spells during the study period both as observed and as simulated and presented by the different domains. Figure 4 presents the number of days of the longest wet-spells again both as observed and as simulated by WRF model.

Table 5. Showing the longest spell observed at each station and how they were simulated by the model at both resolutions.

\begin{tabular}{l|r|r|r}
\hline Station & Observation & Date of occurrence & Domain $2($ d02) \\
\hline Jinja & $21^{\text {st }}-26^{\text {th }}$ October & $17^{\text {th }}$ October $-10^{\text {th }}$ November & $21^{\text {st }}$ October $-8^{\text {th }}$ November \\
Tororo & $11^{\text {th }}-16^{\text {th }}$ october & $9^{\text {th }}-24^{\text {th }}$ October & $9^{\text {th }}-14^{\text {th }}$ October \\
Soroti & $23^{\text {th }} 29^{\text {th }}$ October & $28^{\text {th }}$ October $-9^{\text {th }}$ November & $28^{\text {th }}$ October $-3^{\text {rd }}$ November \\
Serere & $27^{\text {th }}$ October $-4^{\text {th }}$ November & $9^{\text {th }}$ October $-9^{\text {th }}$ November & $27^{\text {th }}$ October $-8^{\text {th }}$ November \\
\hline
\end{tabular}

At Tororo and Soroti stations (Figure 4), WRF model captured the length of the spell (for only the nested domain). However WRF model simulated earlier dates for the start of the spell by three days at Tororo and 6 days at Soroti stations (Table 5). Additionally WRF model presented more days for the wet-spell length for domain 1 (d01) at both the stations. 


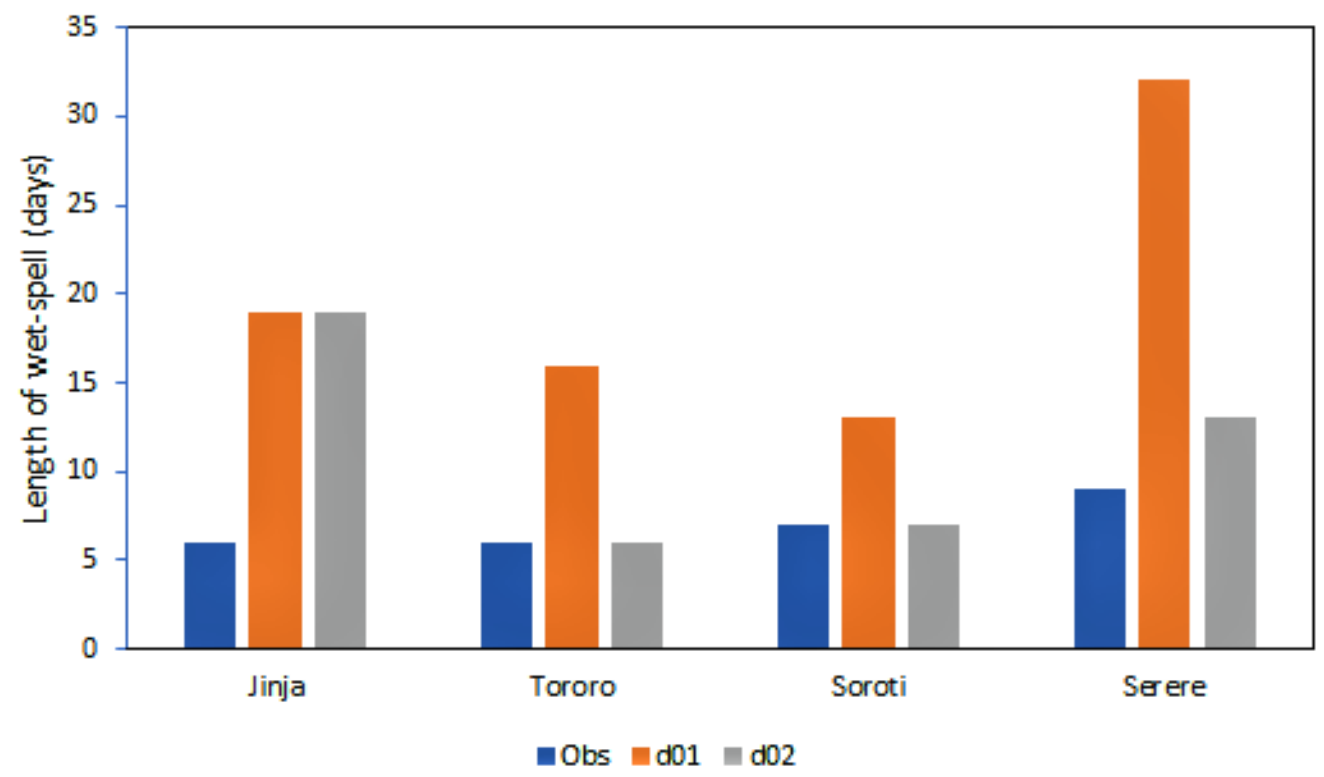

Figure 4. Shows the number of days for the longest duration wet-spells over the study region and during the study period. "Obs" is the observed number of days while "d01" and "d02" are the simulated number of days for domain 1 and domain 2 respectively.

At Jinja and Serere stations (Figure 4), WRF model presented more days for the wet-spell lengths by 13 days for both resolutions and by 23 and 4 days at Serere for d01 and d02 respectively, even though it managed to capture the spell lengths at the other stations. However, the model simulated the same start date of the spell at both the stations for $\mathrm{d} 02\left(21^{s t} \mathrm{Oct}\right)$. Generally, the nested domain ( $\left.\mathrm{d} 02\right)$ presented better prediction values for the onset, cessation dates and the total number of wet days and the length of the wet spells. This is because the nested domain was set at a higher horizontal resolution $(22 \mathrm{Km})$ than the parent domain $(110 \mathrm{Km})$.

Additionally, Pearson correlation analysis between the simulated wet spells and the observed at the different stations was calculated to assess the relationship between then.

The results show that there is no significant relationship between the simulated wet spells for domain 1 at all the stations. Likewise, for domain 2 unlike for Serere which had a p-value of 0.0002 yet it had a relatively higher RMSE (9.24) and ME (-2.04) indices.

Table 6. Values for the Pearson correlation analysis at a confidence level of $95 \%$ between the simulated wet spells and the observed.

\begin{tabular}{|c|c|c|c|c|c|c|l|l|}
\hline Station & \multicolumn{2}{|c|}{ t-value } & \multicolumn{2}{c|}{ P-value } & \multicolumn{2}{|c|}{ R-value(cor) } & \multicolumn{2}{|c|}{ H comment } \\
\hline & D1 & D2 & D1 & D2 & D1 & D2 & D1 & D2 \\
\hline Tororo & -.94 & -0.09 & 0.32 & 0.93 & -0.27 & -0.02 & Reject H0 & Reject H0 \\
\hline Soroti & -0.29 & -0.46 & 0.78 & 0.65 & -0.07 & -0.11 & Reject H0 & Reject H0 \\
\hline Jinja & -.50 & -0.24 & 0.21 & 0.82 & -0.60 & -0.12 & Reject H0 & Reject H0 \\
\hline
\end{tabular}

Furthermore, graphs below (Figure 4) were plotted to show how the model captured the different spell lengths at the different stations. The model simulated more short spells of 1 to 4 days at all the stations. However the model did well in capturing the longer spells unlike for Soroti. There were more short spells of length two days observed at each station. 

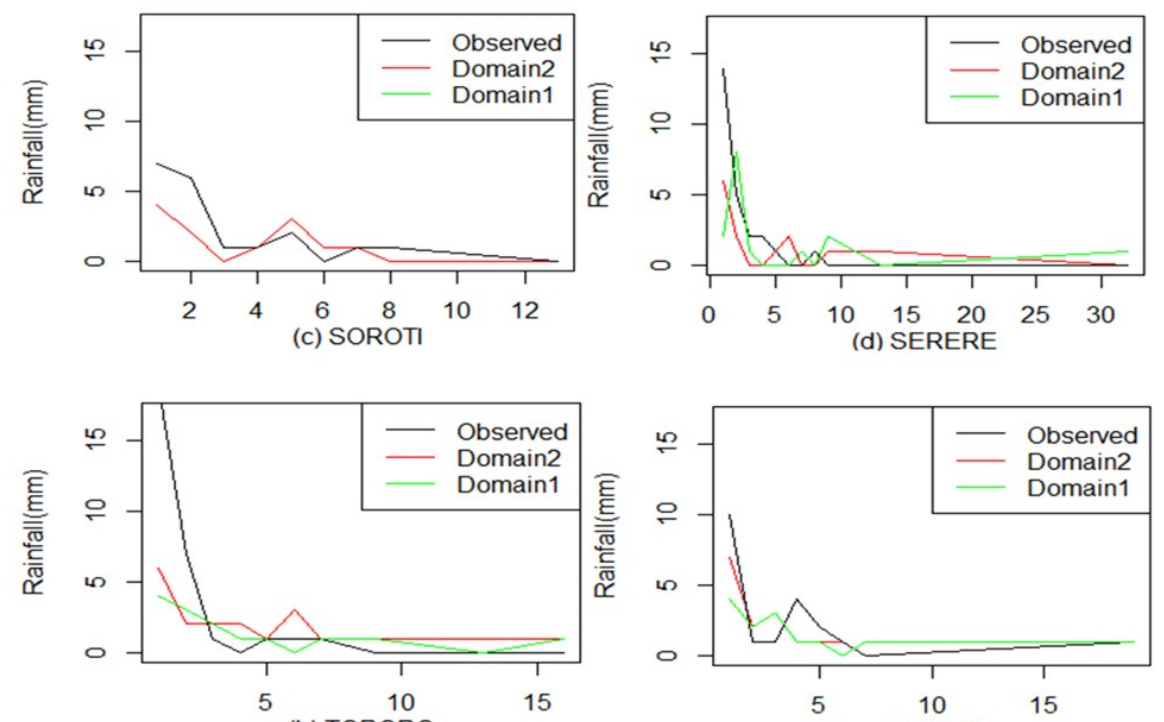

(b) TORORO

(a) JINJA

Figure 5. Plots representing spells against the number of days at different stations.

Furthermore, statistical validation of the model performance was done through the calculation of the ME and the RMSE (Table 5). The results show that the WRF model generally under estimated precipitation for all the stations considered in this study. It had negative ME values at all the stations.

Table 7. Values for RMSE and ME for model performance at different stations.

\begin{tabular}{|c|c|c|c|l|}
\hline Station & \multicolumn{2}{|c|}{ RMSE } & \multicolumn{2}{c|}{ ME } \\
\hline & Domain 1 & Domain 2 & Domain 1 & Domain 2 \\
\hline Jinja & 10.28 & 10.2 & -3.8 & -2.53 \\
\hline Serere & 14.1201 & 14.82 & -4.83 & -5.14 \\
\hline Soroti & 11.67 & 11.84 & -3.79 & -3.79 \\
\hline Tororo & 9.24 & 9.27 & -2.9 & -2.04 \\
\hline & \multicolumn{4}{|l}{} \\
\hline
\end{tabular}

\section{Conclusions}

This study considered the simulation of the intra-seasonal rainfall characteristic using the WRF model. The study was carried out over Eastern Uganda for the SOND rain season of 2015. The datasets used were the daily ground rainfall observations and the lateral and boundary conditions data from the National Centers for Environmental Prediction (NCEP) final analysis at 10 horizontal resolution and 6 hours temporal resolution.

The study found that the WRF model did not capture well the onset and cessation dates but this finding is limited because it was only applied for one season. However, the model generally simulated earlier onset and cessation dates for the season unlike for Jinja for which the model had the same onset date as observed. Additionally, it was observed that the nested domain of the model at a higher horizontal resolution $(22 \mathrm{Km})$ had better simulation results for the onset and cessation dates.

Furthermore, the study investigated the model's ability to simulate the total wet days at each station. The results show that the model generally overestimated the total number of wet days and from the time series plots the model failed to simulate extreme events at each station. The study therefore concludes that the model can simulate wet days.

Additionally, the study investigated the model's ability to simulate the length of wet spells. From the 
results, the model generally simulated the length of spells however with lag of about three days. The model also overestimated the length of some spells.

Author Contributions: R.O.I carried out the experiments and wrote the introduction. I.M designed the simulation experiments and wrote the remain sections

Funding: This research was supported by the project "The Implications of the 1.5 to 2 degree Celsius to Uganda's Climate, Agriculture and Water Nexus" which is funded by the African Academy of Sciences, African Climate Policy Center, DFID and WISER. It is received technical support from the research firm, "Hub for Environmental and Atmospheric Research", HEAR

Acknowledgments: The authors acknowledge the support of Ronald Opio and Jesse Kisembe regarding the assistance rendered during experimentation and data analysis.

Conflicts of Interest: The authors declare no conflict of interest and that the funders had no role in the design of the study; in the collection, analyses, or interpretation of data; in the writing of the manuscript, or in the decision to publish the results.

\section{References}

1. Roger G Barry and Richard J Chorley. MicroRNAs: Atmosphere, Weather and Climate. Cell, 136(2):215-233, 012003.

2. Wallace and Hobbs. MicroRNAs: Atmospheric science: an introductory survey. Cell, 92(2):215-233, 012006.

3. Mugume I., Waiswa D., Mesquita M. D. S., Reuder J., Basalirwa C., Bamutaze Y., and Ayesiga G. (2017)]Mugume, I., Waiswa, D., Mesquita, M. D. S., Reuder, J., Basalirwa, C., Bamutaze, Y., and Ayesiga, G.., "Assessing the performance of WRF model in simulating rainfall over western Uganda.," Journal of Climatology Weather Forecasting,pp.5, 1-9, 2017

4. Omondi, P., Awange, J. L., Ogallo, L. A., Okoola, R. A., and Forootan, E., “Decadal rainfall variability modes in observed rainfall records over East Africa and their relations to historical sea surface temperature changes," Journal of Hydrology,pp. 464, 140-156, 2012

5. Otieno, G., " Assessing The Skill Of The Seasonal Rainfall Prediction Over The Greater Horn Of Africa Using Global Models As Multimodel Ensemble.," Department of Meteorology, University of Nairobi,pp.5, 2013

6. Pizarro, R., Garcia-Chevesich, P., Valdes, R., Dominguez, F., Hossain, F., Ffolliott, P. ... and Bro, P., “Inland water bodies in Chile can locally increase rainfall intensity," Journal of hydrology, pp.481, 56-63, 2013

7. T.-H. Yang, S.-C. Ho, J.-Y. Lin, G.-F. Hwang, G.-D. \& Lee, C.-S., “ Flash flood warnings using the ensemble precipitation forecasting technique: a case study on forecasting floods in taiwan caused by typhoons," Journal of hydrology, pp.520, 367-378, 2015.

8. Seneviratne, S. I., Nicholls, N., Easterling, D., Goodess, C. M., Kanae, S., Kossin, J., ... \& Reichstein, M., Changes in climate extremes and their impacts on the natural physical environment: An overview of the IPCC SREX report.," In EGU General Assembly Conference Abstracts , Vol. 14, p. 12566 , 2012, April.

9. Nyakaisiki, K., Mugume, I., Ngailo, T., \& Nakabugo, R. "The Use of Indigenous Knowledge in Predicting Changes in Seasonal Rainfall by Smallholder Farmers of Ruteete Subcounty, Kabarole District". Journal of Geoscience and Environment Protection, 7, 13-22, 2019.

10. Call, Maia, Clark Gray, \& Pamela Jagger. "Smallholder responses to climate anomalies in rural Uganda." World Development, 2019, 115: 132-144.

11. Kazembe, A., "Determining the onset and cessation of seasonal rains in Malawi," Conference on Multimedia,2014.

12. Trenberth, K. E., Dai, A., Rasmussen, R. M., \& Parsons, D. B.," The changing character of precipitation.," Bulletin of the American Meteorological Society, 84(9), 1205-1218, 2003.

13. Stampone, M. D., Hartter, J. N., Chapman, C. A., \& Ryan, S. J.," Trends and variability in localized precipitation around Kibale National Park, Uganda, Africa," Research Journal of Environmental and Earth Sciences, 2011.

14. Shongwe, M. E., Lennard, C., Liebmann, B., Kalognomou, E., and Ntsangwane, L.," An evaluation of CORDEX regional climate models in simulating precipitation over Southern Africa," https://doi.org/10.1002/asl2.538, 199-207, October 2014

15. Gitau, W., "Characteristics of the wet and dry spells during the wet seasons," journal, 2005. 
16. Stern, N.," Stern review report on the economics of climate change," Proceedings of the Third IEEE International Conference on Multimedia, 2006.

17. Majaliwa, J. G. M., Tenywa, M. M., Bamanya, D., Majugu, W., Isabirye, P., Nandozi, C., ... \& Rao, K. P. C.," Characterization of Historical Seasonal and Annual Rainfall and Temperature Trends in Selected Climatological Homogenous Rainfall Zones of Uganda," Global Journal of Science Research, pp.15, 21-40, 2015.

18. Graedel, T. E., Allwood, J., Birat, J. P., Reck, B. K., Sibley, S. F., Sonnemann, G., and Hagelüken, C., “ UNEP Recycling Rates of Metals-A Status Report," A Report of the Working Group on the Global Metal Flows to the International Resource Panel, United Nations Environment Programme, 2011.

19. World Bank. Information, Communication Technologies, \& infoDev (Program). (2012)., "Information and communications for development 2012: Maximizing mobile," World Bank Publications, 2012.

20. Ogallo, L. J., and Chillambo, W. A., " The characteristics of wet spells in Tanzania," East African Agricultural and Forestry Journal,pp.47, 87-95, 1981.

21. Mugume, Isaac, et al. "Improving Quantitative Rainfall Prediction Using Ensemble Analogues in the Tropics: Case Study of Uganda." Atmosphere 9.9 (2018): 328.

22. Mugume, Isaac. Optimization of numerical models for operational weather forecasting in Uganda. $P h D$ Thesis, 2018.

23. Gebremichael, A., Quraishi, S., \& Mamo, G., “ Analysis of Seasonal Rainfall Variability for Agricultural Water Resource Management in Southern Region, Ethiopia Inter tropical Convergence Zone Length of Growing Period," Journal of Natural Sciences Research , pp.4, 56-80, 2014

24. Wiyo, K. A., Kasomekera, Z. M., and Feyen, J., “ Effect of tied-ridging on soil water status of a maize crop under Malawi conditions," Agricultural Water Management , pp.45, 101-125, 2000.

25. Washington, R., James, R., Pearce, H., Pokam, W. M., Moufouma-okia, W., \& Washington, R., " Circulation controls on southern African precipitation in coupled models," Climate journal, pp.122, 861-877, 2017.

26. Omotosho, J. B., Balogun, A. A., \& Ogunjobi, K.," Predicting monthly and seasonal rainfall, onset and cessation of the rainy season in West Africa using only surface data," International Journal of Climatology: A Journal of the Royal Meteorological Society,pp.20, 865-880,2000.

27. Bouagila, B., and Sushama, L., " On the current and future dry spell characteristics over Africa," Atmosphere, pp.4, 272-298, 2013.

28. Wang, B., Liu, D.-L., Evans, J. P., Ji, F., Waters, C., Macadam, I., Feng, P. \& Beyer, K. "Modelling and evaluating the impacts of climate change on three major crops in south-eastern Australia using regional climate model simulations." Theoretical and Applied Climatology, 2019: 1-18.

29. Ngailo, T.J., Shaban, N., Reuder, J., Mesquita, M.D., Rutalebwa, E., Mugume, I. and Sangalungembe, C., "Assessing Weather Research and Forecasting (WRF) Model Parameterization Schemes Skill to Simulate Extreme Rainfall Events over Dar es Salaam on 21 December 2011". Journal of Geoscience and Environment Protection, 6(01), p.36.

30. Skamarock, W. C., Klemp, J. B., Dudhia, J., Gill, D. O., Barker, D. M., Wang, W., \& Powers, J. G. "A description of the advanced research WRF version 2 (No. NCAR/TN-468+ STR)". National Center For Atmospheric Research Boulder Co Mesoscale and Microscale Meteorology Div. 2005

31. Kansiime, M. K., \& Shisanya, C., "Perceived and Actual Rainfall Trends and Variability in Eastern Uganda," Implications for Community Preparednes, January 2013.

32. Kisembe, J., Favre, A., Dosio, A., Lennard, C., Sabiiti, G., \& Nimusiima, A. "Evaluation of rainfall simulations over Uganda in CORDEX regional climate models". Theoretical and Applied Climatology, 1-18. 2018

33. .Waiswa, M., “ Assessment Of Spatial And Temporal Characteristics Of The December-February Seasonal Rains Over Uganda," Climate journal, july 2015.

34. Kain, J. S. \& Fritsch, J. M. "Convective parameterization for mesoscale models: The Kain-Fritsch scheme". In The representation of cumulus convection in numerical models (pp. 165-170). American Meteorological Society, Boston, MA. 1993

35. Hong, S. Y. \& Lim, J. O. J. "The WRF single-moment 6-class microphysics scheme (WSM6)". Asia-Pacific Journal of Atmospheric Sciences, 42(2), 129-151. 2006

36. Stern, R., Rijks, D., Dale, I., \& Knock, J. "INSTAT climatic guide". Reading (UK): University of Reading. 2006

37. Kumi, N. \& Abiodun, B. J. "Potential impacts of $1.5^{\circ} \mathrm{C}$ and $2^{\circ} \mathrm{C}$ global warming on rainfall onset, cessation and length of rainy season in West Africa". Environmental Research Letters, 13(5), 055009. 2018 
38. Mugume, I., Basalirwa, C., Waiswa, D., Reuder, J., Mesquita, M. D. S., Tao, S., \& Ngailo, T. J. "Comparison of parametric and nonparametric methods for analyzing the bias of a numerical model". Modelling and Simulation in Engineering, 2016, 6.

39. Tao, S., Li, Y., \& Mugume, I. "Model terrain correction using variational adjoint method with Tikhonov-total variation regularization". Journal of Physics: Conference Series (Vol. 1176, No. 2, p. 022034). IOP Publishing. 2019.

40. Dunning, C. M., Black, E. C., Allan, R. P. "The onset and cessation of seasonal rainfall over Africa". Journal of Geophysical Research: Atmospheres, 121(19), 11-405. 2016

41. Mounkaila, M. S., Abiodun, B. J., Omotosho, J. B. (2015). Assessing the capability of CORDEX models in simulating onset of rainfall in West Africa. Theoretical and applied climatology, 119(1-2), 255-272.

Sample Availability: Samples of the compounds ...... are available from the authors. 